\title{
Status of Antioxidant Enzymes and Mercury Levels Between Traditional Gold Miners and Non Miners
}

\author{
Siti Thomas Zulaikhah \\ Department of Public Health, Faculty of Medicine, Sultan Agung Islamic University (UNISSULA) Semarang, Central Java, Indonesia
}

\begin{abstract}
Background: Gold mining is traditionally processed by the method of amalgamation, that is a process using mercury to bind to gold. Mercury is free radical able to increase the Reactive Oxygen Species (ROS), inhibit enzymes, interfere with the metabolism of the body antioxidants, especially superoxide dismutase (SOD) and glutathione peroxidase (GPX). Low levels of antioxidant enzymes can be used as a parameter indicating that level of free radicals in the body is high. Low levels of antioxidant enzymes is caused by the reduction of thiol group on the antioxidant enzyme protein as it is bound by mercury, because these compounds have a strong affinity for thiol clusters. This study is aimed at determining whether there is difference of the status of antioxidant enzymes between nonminers and traditional gold miners. Methods: Observational design used cross sectional design. The samples were 30 non miners and 32 miners, sampling technique was simple random. Status antioxidants including SOD level, catalase, and GPX were measured by Elisa method. Level of mercury was measured by method of Mercury Analyser Cold Vapour. Data were analyzed by $t$ - independence test due to the normal data distribution. Results: The mean level of mercury in non-miners was 40,89 $\mu \mathrm{g} / \mathrm{L}$ and that of miners was $104,49 \mu \mathrm{g} / \mathrm{L}$, the level of SOD of non miners was $365 \mathrm{U} / \mathrm{mL}$ and that of the miners was $219 \mathrm{U} / \mathrm{mL}$, the catalase level of non miner was $5,48 \mathrm{U} / \mathrm{mL}$, and that of miners was 3,35 U/mL, GPx level of non miners was $90,85 \mathrm{U} / \mathrm{mL}$, and that of miners was $51,88 \mathrm{U} / \mathrm{mL}$. The analysis results showed that p-value was 0.000 . Conclusions: There are significant differences in the status of antioxidant enzymes and mercury levels in both groups of miners and non traditional gold miners.
\end{abstract}

Keywords: SOD, catalase, GPx, mercury, ROS

\section{Intoduction}

Mercury $(\mathrm{Hg})$ is highly toxic metal, which can result in very dangerous impact for the health disturbances in the central nervous system, kidney, respiratory tract, immune system, skin, reproduction and developmental disorders. ${ }^{1}$ Mercury can also cause damage to biochemical tissue and gen through various mechanisms such as intracellular calcium homeostasis disturbance, disrupt potential membrane, change the protein synthesis, disrupt the path of amino acids in the central nervous system. ${ }^{2}$ Mercury is widely used in industrial processes, such as industries of thermometers, hydrometers, barometers, sphygmomanometers, floerescent light, batteries, pesticides, plastics, caustic soda, chlorinealkali, gold mining and used in the laboratory. ${ }^{3-5}$ Globally, the largest sources of mercury emissions result from traditional gold mining. ${ }^{5}$ In Indonesia, approximately $57.5 \%$ of mercury emission sources also come from traditional gold mining with the total of emission is about 195 tons/year. In 2010 there were approximately 900 locations covering about 250.000 workers involved in traditional gold mining. ${ }^{6}$

One of the areas in Central Java province, precisely around the mountain Randukuning, Sub District of Selogiri, Wonogiri Regency there are gold mining activities traditionally done. The results of mining are processed by the method of amalgamation, that is the extraction process and binding the gold metal from ore using mercury. Mercury penetrates into the body through inhalation or skin during the process of evaporation, so that mercury in the form of vapor is inhaled into the lungs and approximately $80 \%$ will be absorbed and distributed throughout the body. ${ }^{7}$ Results of a preliminary survey conducted by Rianto in 2010 showed that about 87 workers had high blood mercury levels, that was $6.07 \mu \mathrm{g} / \mathrm{L}-257,87 \mu \mathrm{g} / \mathrm{L}$. ${ }^{8}$ The average of blood mercury levels exceeded the threshold allowed by WHO $\geq 10 \mathrm{~g} / \mathrm{L}$.
This condition can describe that the traditional gold miners are at risk for mercury poisoning .

Mercury is a free radical that can increase the formation of Reactive Oxygen Species (ROS) such as hydrogen peroxide $\left(\mathrm{H}_{2} \mathrm{O}_{2}\right)$, superoxide $\left(\mathrm{O}_{2} \bullet\right)$ and hydroxyl radical $(\bullet \mathrm{OH})$, increase lipid peroxidation, cause DNA damage and cause oxidative stress. ${ }^{9-10}$. The attack of free radical on lipids causes lipid peroxidation reaction. The harmful impact of the mercury accumulation in the body is releasing ROS and increasing lipid peroxidation in the cell. ${ }^{11}$. The emergence of the action of ROS is caused by low antioxidant system so that its activity in counteracting ROS will not be perfect. Low defence system of antioxidants is caused by the reduction of thiol cluster in antioxidants protein and antioxidant enzymes as it is bound by mercury, so it leads to depletion of antioxidants and decreases activity of antioxidant enzymes such as superoxde dismutase (SOD), catalase (CAT) and glutathione peroxidase (GPx), this condition can cause the depletion of reduced glutathione levels and accumulation of $\mathrm{H}_{2} \mathrm{O}_{2}$, which in turn causes oxidative damage in the cell membrane. ${ }^{12,13}$. Oxidative stress occurs resulting from the amount of ROS in the body exceeds the amount of antioxidants, in which the excess will attack the components of lipids, proteins , and DNA. ${ }^{14}$

Some studies reported that rats induced mercury increased ROS production, lowering antioxidant enzymes SOD, CAT and $\mathrm{GPx}^{4}{ }^{4}{ }^{15,16}$ The research by $\mathrm{Al}$ - azzawie et al., 2013 proves that the long term exposure to mercury significantly relates to high level of mercury in the blood and blood mercury level affects the level of SOD, CAT and GPx in workers exposed to mercury. Various efforts have been made by relevant agencies with regard to minimizing mercury exposure among others by the use of PPE , especially during the evaporation process of gold ore. However, most of the miners have been poisoned by 


\section{International Journal of Science and Research (IJSR) \\ ISSN (Online): 2319-7064 \\ Index Copernicus Value (2013): 6.14 | Impact Factor (2014): 5.611}

mercury in which blood mercury level is $\geq 10 \mathrm{~g} / \mathrm{L}$. This study is aimed at determining whether there is the difference of the status of antioxidant enzymes between non miners and traditional gold miners.

\section{Methode}

The study design was observational analytic with cross sectional design. ${ }^{17}$ The study population was the entire population living in the village of Jendi, Selogiri Wonogiri in 2014. Samples were obtained by Simple Random Sampling method. The samples were 32 miners and 30 non miners who met the inclusion and exclusion criteria. ${ }^{18}$

The inclusion criteria of miners: living in Selogiri, male, age 20-60 years, working as a gold miner, a normal BMI, willing to become respondents. The inclusion criteria of non miners: living in Selogiri, male, aged 20-60 years, not working as a gold miner, a normal BMI, willing to become respondents. The exclusion criteria: having disorder of the immune system, heart and brain infarction, pulmonary tuberculosis, diabetes, sepsis and severe infection or other disorders. Mercury level was checked by a method of Mercury Analyser Cold Vapour in Environmental Health Engineering Center for Disease Control in Yogyakarta, while examination of SOD, CAT and GPx as status parameter of antioxidant enzyme was conducted in the laboratory of PAU Gajah Mada University Yogyakarta with the reagent kit from Randox. Statistical testing used to analyze the data was $t$-independence due to the normal distributed data.

\section{Results}

Table 1: Results of the examination of mercury level, antioxidant enzymes SOD, CAT and GPx in the group of non miners and traditional gold miners

\begin{tabular}{|c|c|c|c|}
\hline \multirow{2}{*}{ Parameter } & \multicolumn{2}{|c|}{ Mean \pm SD } & p-value \\
\cline { 2 - 3 } & $\begin{array}{c}\text { Non Miners } \\
(\mathrm{n}=30)\end{array}$ & $\begin{array}{c}\text { Miners } \\
(\mathrm{n}=32)\end{array}$ & \\
\hline Mercury $(\mu \mathrm{g} / \mathrm{L})$ & $40.89 \pm 20.83$ & $104.49 \pm 29.27$ & 0.000 \\
\hline SOD $(\mathrm{U} / \mathrm{mL})$ & $365 \pm 5.53$ & $219 \pm 5.69$ & 0.000 \\
\hline CAT $(\mathrm{U} / \mathrm{mL})$ & $5.48 \pm 0.96$ & $3.35 \pm 0.91$ & 0.000 \\
\hline GPx $(\mathrm{U} / \mathrm{mL})$ & $90.85 \pm 13.62$ & $51.88 \pm 14.72$ & 0.000 \\
\hline
\end{tabular}

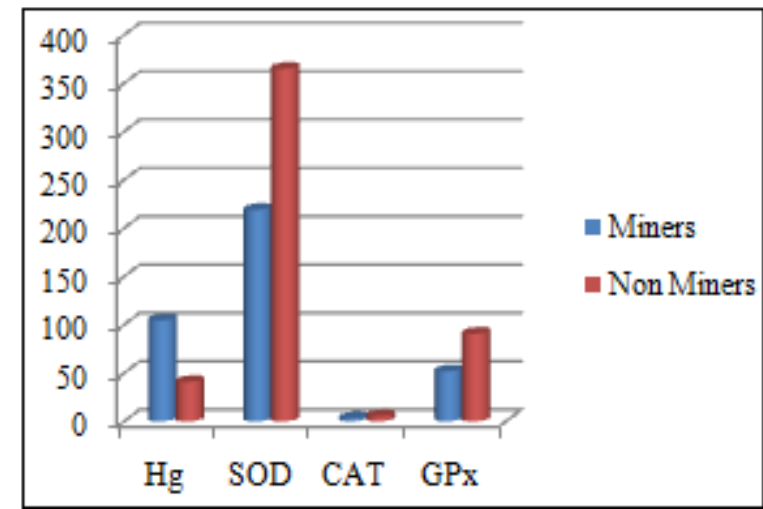

Figure 1: Results of the examination of mercury level, antioxidant enzymes SOD, CAT and GPx in the group of non- miners and traditional gold miners

Based on the table and figure 1, it was obtained that the average of mercury level in group of miners was higher than that of non miners $(104.49 \pm 29.27$ vs $40.89 \pm 20.83 \mu \mathrm{g} / \mathrm{L})$, an antioxidant enzyme including SOD, CAT and GPX in the group of non miners was higher than in the group of miners (SOD $365 \pm 5.53$ vs $219 \pm 5.69 \mathrm{U} / \mathrm{mL})$, CAT $(5.48 \pm 0.96$ vs $3.35 \pm 0.91 \mathrm{U} / \mathrm{mL})$, GPx $(90.85 \pm 13.62$ vs $51.88 \pm 14.72$ $\mathrm{U} / \mathrm{mL})$. The result of statistical analysis with $t$ independence obtained p-value was 0.000 , in which the $\alpha: 5$ $\%$ can be said there was a significant difference between the level of mercury, SOD, CAT, and GPX in the group of non miners and traditional gold miners .

\section{Discussion}

The results showed that there were significant differences between the average of mercury level in non- miners and miners group $(p<0.05)$. These results are consistent with the study of Al - Azzawie et al. ${ }^{19}$ stating that there were differences in average levels of mercury between the group not exposed to mercury, groups of workers exposed to mercury $<10$ years and groups of workers exposed to mercury $>10$ years $(p<0.01)$. Gold mining traditionally done in Jendi village, Wonogiri Selogiri is processed by the method of amalgamation, that is the process of binding metallic gold from the ore using mercury. In the process and the extraction of gold, a large amount of mercury is used to form amalgam with the gold. Amalgam is then heated so the mercury evaporates, resulting in a large release of mercury in the atmosphere. ${ }^{20,21}$ The mining waste from the amalgamation process containing mercury is directly discharged into the environment without prior process, so it contaminates the environment. As many as 10-30\% of mercury used in these activities will be released or lost into the environment. ${ }^{22}$

Mercury can penetrate into the body through inhalation or skin during the process of evaporation so the mercury in the form of vapor is inhaled into the lungs and approximately 80 $\%$ will be absorbed and distributed throughout the body. Mercury can also penetrate the body through food or beverages such as consuming mercury contaminated well water, eating vegetables produced from mercurycontaminated soil, using cooking utensils and cutlery contaminated mercury etc.

The results showed that there were significant differences between the average levels of SOD, CAT and GPx in the group of non miners and miners $(p<0.05)$. These results are consistent with studies of Al-Azzawie et al. ${ }^{19}$ that stated there were differences in average levels of SOD, CAT and GPx between the group not exposed to mercury, groups of workers exposed to mercury $<10$ years and groups of workers exposed to mercury $>10$ years $(p<0.01)$. In the group of miners, mercury exposure was more than that of the non miners, it can be seen from the average blood mercury levels in the group of miners was higher (104.49 $\mu \mathrm{g} / \mathrm{L})$ than that of the group of non- miners $(40.90 \mu \mathrm{g} / \mathrm{L})$.

Mercury is free radical that can increase the formation of Reactive Oxygen Species (ROS) such as hydrogen peroxide $\left(\mathrm{H}_{2} \mathrm{O}_{2}\right)$, superoxide $\left(\mathrm{O}_{2} \bullet\right)$ and hydroxyl radical $(\bullet \mathrm{OH})$, causing damage to DNA and promoting oxidative stress on cells or tissues. ${ }^{9,10}$ The harmful impact of the mercury accumulation in the body is releasing ROS. The emergence 


\section{International Journal of Science and Research (IJSR) \\ ISSN (Online): 2319-7064}

Index Copernicus Value (2013): 6.14 | Impact Factor (2014): 5.611

of the action of ROS as a result of high level of free radical can reduce body antioxidant enzyme systems so that the activities to encounter ROS will not be perfect. The low antioxidant defense system is resulted from the reduction of thiol cluster in protein antioxidant enzymes as it is bound by mercury, causing thinning and decreasing the activity of antioxidant enzymes such as glutathione peroxidase (GPx , superoxide dismutase (SOD) and catalase (CAT), this condition can lead to depletion of reduced glutathione level and accumulation of $\mathrm{H}_{2} \mathrm{O}_{2}$, which in turn leads to a build-up of hydroxyl radicals that are more reactive and dangerous that they can trigger oxidative damage in the cell membrane. ${ }^{12,13}$ The high level of ROS in the body can be shown by the low antioxidant enzymes of SOD, CAT and GPx. Oxidative stress occurs as the amount of ROS exceeds the amount of antioxidants in the body, in which the excess will attack the components of lipids, proteins, and DNA. ${ }^{14}$

Some studies report that rats induced by mercury suffer from oxidative stress due to the depletion of the thiol especially $\mathrm{GSH}$, increasing the production of ROS, lowering antioxidant enzymes SOD, CAT and GPx, and increasing $\mathrm{H}_{2} \mathrm{O}_{2}{ }^{4,15,16}$ Antioxidant enzymes are also known as primary antioxidants. A compound is considered to be a primary antioxidant, if it can provide hydrogen atom rapidly to the radicals, then the formed antioxidant radical is soon turned into a more stable compound. Antioxidant enzyme works by preventing the formation of new free radical compounds, or change the formed free radicals into a less active molecule. As the antioxidants, these enzymes inhibit the formation of free radicals by breaking the chain reaction (polymerization ), then turn it into a more stable product. ${ }^{14}$

Antioxidant enzymes include superoxide dismutase (SOD), catalase, glutathione peroxidase (GPx), and glutathione reductase (GSH - R). These enzymes work by protecting tissues from oxidative damage caused by free radicals of oxygen such as superoxide anion $\left(\mathrm{O}_{2} \bullet-\right)$, hydroxyl radicals $(\mathrm{OH} \bullet)$ radical peroxyl (ROO•) and hydrogen peroxide $\left(\mathrm{H}_{2} \mathrm{O}_{2}\right) \cdot{ }^{14,23} \mathrm{SOD}$ enzymes function as a catalyst of dismutasi reaction from superoxide anions to hydrogen peroxide $\left(\mathrm{H}_{2} \mathrm{O}_{2}\right)$ and oxygen $\left(\mathrm{O}_{2}\right)$.

$$
\mathrm{O}_{2} *^{-}+\mathrm{O}_{2} *^{-}+{ }_{2} \mathrm{H}^{+} \stackrel{\mathrm{SOD}}{\longrightarrow} \mathrm{H}_{2} \mathrm{O}_{2}+\mathrm{O}_{2}
$$

This enzyme has existed in the body, but it requires mineral nutrient assistance such as mangane (Mn ), zinc ( $\mathrm{Zn})$, and copper $(\mathrm{Cu})$ to work. The activity of SOD enzyme has an important role in the system of body immune, especially the activity of reactive oxygen compounds causing oxidative stress. $^{14}$.

Catalase (CAT) is a heme-containing enzyme homotetramer, catalysing dismutasi hydrogen peroxide $\left(\mathrm{H}_{2} \mathrm{O}_{2}\right)$ into water and oxygen. ${ }^{14,23}$ This enzyme is found in all types of eukaryotic aerobic, which is necessary to destroy $\mathrm{H}_{2} \mathrm{O}_{2}$ formed in peroxisomes via the oxidation reaction. This enzyme is able to oxidize one molecule of hydrogen peroxide into water $\left(\mathrm{H}_{2} \mathrm{O}\right)$ and oxygen $\left(\mathrm{O}_{2}\right)$.

$$
2 \mathrm{H}_{2} \mathrm{O}_{2} \stackrel{\text { Catalase }}{\longrightarrow} 2 \mathrm{H}_{2} \mathrm{O}+\mathrm{O}_{2}
$$

Cells containing small amounts of catalase are very vulnerable to peroxidation attack, therefore catalase has an important role in the cellular defense mechanism against hydrogen peroxide oxidator. The activity of catalase enzyme can be induced by the intake of antioxidants. ${ }^{14}$.

Glutathione peroxidase (GPx) is an antioxidant enzyme containing selenium (Se) on the active side. This enzyme works on reduced glutathione $(\mathrm{GSH})$ and $\mathrm{H}_{2} \mathrm{O}_{2}$ to produce oxidized glutathione (GSSH) and $\mathrm{H}_{2} \mathrm{O} .{ }^{14,23}$ The activity of the enzyme glutathione peroxidase can reduce $70 \%$ of organic peroxides, and more than $90 \% \mathrm{H}_{2} \mathrm{O}_{2}{ }^{14}$ In order for these enzymes to work, it is always necessary to have a substrate, such as glutathione, which is peroxidase glutathione enzyme substrate.

$$
2 \mathrm{GSH}+\mathrm{H}_{2} \mathrm{O}_{2} \stackrel{\mathrm{GPx}}{\longrightarrow} \mathrm{GSSH}+2 \mathrm{H}_{2} \mathrm{O}
$$

The role of antioxidant enzymes of SOD, catalase and GPx in eliminating ROS presented in Figure 2 below :

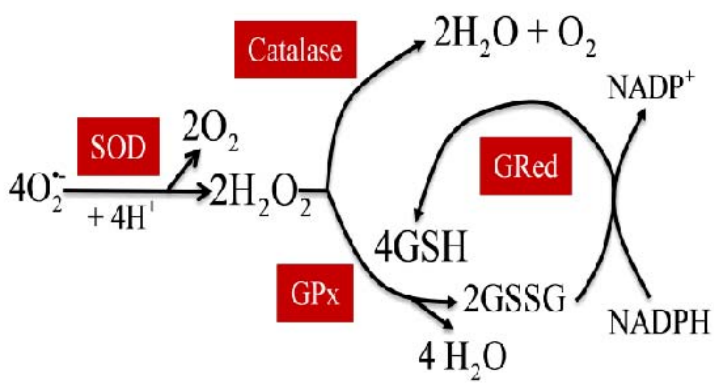

Figure 2: The role of SOD, catalase and GPx in eliminating ROS. $^{24}$

\section{Conclusion}

There is significant difference between the levels of mercury, the status of antioxidant enzymes of SOD, CAT and GPx in the group of traditional gold miners and non miners in Selogiri, Wonogiri, Central Java, Indonesia.

\section{Ethics approval}

This study has obtained permission from the Health Research Ethics Committee (IEC) Diponegoro University School of Medicine and Hospital, Dr. Kariadi with ethical clearance no. 481/EC/FK-RSDK/2014).

\section{Acknowledgements}

This research was supported by Faculty of Medicine, Sultan Agung Islamic University (UNISSULA) Semarang. The Author would like to thank the miners and non traditional gold miners (respondents) for their contribution.

\section{Conflict of interest}

The Authors declared no conflict of interest

\section{References}

[1] Risher, J.F., S.N. Amler. 2002. Mercury exposure: evalution and intervention the inappropriate use of chelating agents in the diagnosis and treatment of 


\section{International Journal of Science and Research (IJSR) \\ ISSN (Online): 2319-7064}

Index Copernicus Value (2013): 6.14 | Impact Factor (2014): 5.611

putative mercury poisoning. Neurotoxicology 26:691699.

[2] LynPatrick. N.D. 2002. Mercury Toxicity and Antioxidans : Part I: Role of Glutathione and AlphaLipoic Acid in the Treatment of Mercury Toxicity. Alternative Medicine Review 7(6): 456-467

[3] Choi, A.L., P. Grandjean. 2008. Metylmercury exposure and health effects in human : a review of the literature, Environ. Chem. $5: 112-120$

[4] Varadharajan, V., J. Ganesan. 2013. Restoration Of Antioxidant Avtivity By N-Acetylcysteine and Gallic Acid on Kidney Tissue of Mercury Chloride intoxicated Wistar Rats. International Journal of Biological \& Pharmaceutical Research 4(4) : 302-307

[5] UNEP. 2013. Global Mercury Assessment : Sources, Emissions, Releases and Environmental Transport. pp 24,27

[6] Kementerian Energi dan Sumber Daya Mineral RI . 2013. Rencana Aksi Nasional Penghapusan Penggunaan Merkuri pada Pengolahan Emas 2014-2018. Tim Teknis Penyusunan Rencana Aksi Nasional Penghapusan Penggunaan Merkuri pada Pengolahan Emas

[7] National Research Council (NRC). 2000. Effect of Metyhmercury Board on Environmental Studies and Toxicology Commision on Life Sciences. Toxicological Effect of Metyhmercury. National Academy Press. Washington DC.

[8] Rianto, S. 2010. Analisis faktor-Faktor yang Berhubungan dengan Keracunan Merkuri pada penambang Emas Tradisional di desa jendi Kecamatan selogiri kabupaten Wonogiri. Tesis. (Online). (http://epints.undip.ac.id/23843/1/SUGENG_RIANTO. pdf. diakses 12 November 2012

[9] Houston, M.C. 2007. The role of mercury and cadmium heavy metals in vascular disease, hypertension, coronary heart disease and myocardial infarction," Alternative Therapies in Health and Medicine13(2) : S128-S133.

[10] Komousani, T. A., s.S. Mouselhy. 2011. Modulation of lead biohazards using a combination of epicatechin and lycopene in rats. Human and Experimental Toxicology 30(10) :1674-1681

[11]Durak, D., S.Kalender, F.G.Uzun, F.DemirdanY. Kalender. 2010. Mercury chlorida-induced oxidative stress in human erytrhrocytes and effect of vitamin $\mathrm{C}$ and $\mathrm{E}$ in vitro. African Journal of Bitechnology 9(4) : 488-495

[12] Windham. 2005. Effect Neurologist Mercury Exposure. Available: www. Flcv.com/neurohg.html. (Akses 3 Juni 2013)

[13] Sharma, M.K., M. Kumar, A. Kumar. 2002. Ocimum sanctum aqueous leaf extract provides protection against mercury induced toxicity in Swis albino mice. Indian Journal of Experimental Biology 40:1079-1082

[14] Winarsi, H. 2007. Antioksidan Alami \& Radikal Bebas, Potensi dan Aplikasinya dalam Kesehatan. Kanisius. Yogyakarta.

[15]Flora, S.J.S., M. Mittal, A. Mehta. 2008. Heavy Metal Induced Oxidative Stress \& Its Possible Reversal by Chelation Therapy. Indian J Med Res 128: 501-523

[16]Jan, A.T., A. Ali, Q.M.R. Haq. 2011. Glutation as an Antioxodant in Inorganic Mercury Induced Nephrotoxicity. Review Article 57(1): 72-77
[17] Sastroasmoro, S. S. Ismael. 2011. Dasar-Dasar Metodologi Penelitian Klinis. edisi 4. Sagung Seto. Jakarta

[18]Dahlam, M.S. 2014. Pintu Gerbang Memahami Statistik, Metodologi, dan Epidemiologi. Sagung Seto. Jakarta

[19] Al-azzawie, H.F., A. Umran, N.H. Hyader. 2013. Oxidative Stress, Antioxidant and DNA Damage in a Mercury Exposure Workers. British Journal of Pharmacology and Toxicology 4(3): 80-88.

[20]ATSDR. 1999. Toxicological Profile for Mercury (update). Agency for Toxic Substances and Disease Registry. Atlanta. Georgia

[21] Eisler, R. 2003. Health risk of gold miners: A synoptic review. Environ Geochem Health 25:325-345.

[22] Susilo, Y.E.B. 2003. Мепији Keselarasan Lingkungan - memahami Sikap Teologis Manusia terhadap Pencemaran Lingkungan. Averroes Pres. Malang.

[23] Murray, R.K., D.K.Granner, V.W. Rodwell. 2009. Biokimia Harper, edisi 27. EGC, Jakarta. p 508560;636-641

[24] Kunwar A, Priyadarsini KI. Review. Free Radikal Stress and Importance of Antioxidants in human Health. Journal Medical \& Allied Sciences. 2011;1:53-60. 